\title{
Arte, Individuo y Sociedad
}

ISSN: 1131-5598

\section{Mad Men and television aesthetics: Final shots as a tool for textual configuration}

\author{
Miguel A. Huerta ${ }^{1}$; Ernesto Pérez ${ }^{2}$
}

Recibido: 24 de octubre de 2018 / Aceptado: 8 de marzo de 2019

\begin{abstract}
Academic studies of Mad Men confirm that television aesthetics awaken a secondary interest among scholars. The present work joins the body of critical literature that defends the importance of style to television programming. In spite of the thrust and value of the new results achieved by television aesthetics, it is enough to look into the existing bibliography about works like Mad Men to arrive at the conclusion that their scope continues to be comparatively residual. In concrete terms, a formal analysis (scale, placing, length, angle, movement, composition, etc.) of the 'shot unit' related to this series is proposed. This will examine the 92 units that comprise the final shot of each episode of Mad Men, to yield the quantitative and qualitative elements that help forge the 'aesthetic of emptiness' that characterizes the TV show created by Matthew Weiner. The final images of each installment make up a kind of unhurried ritual in which the television form portrays a man on his own, trapped in an oppressive setting and unable to progress dramatically.
\end{abstract}

Keywords: Television Aesthetics; Style; Shot; Mad Men; aesthetic of emptiness.

\section{[es] Mad Men y la estética televisiva: los planos finales como herramienta de configuración textual}

Resumen. Los estudios académicos sobre Mad Men confirman que la estética televisiva despierta un interés secundario en comparación con otras perspectivas. El presente trabajo se suma a la premisa de quienes defienden la necesidad de conocer las cualidades estilísticas de los textos generados por el medio. A pesar de los valiosos hallazgos logrados en el campo de la estética televisiva, basta con examinar la bibliografía existente sobre obras como Mad Men para concluir que su influencia sigue siendo residual. En concreto, se propone en este trabajo un método de análisis formal (escala, situación, duración, ángulo, movimiento, composición, etcétera) basado en la unidad 'plano'. Desde esta perspectiva se examinan las 92 unidades que componen los últimos planos de cada capítulo de Mad Men para alcanzar resultados tanto cuantitativos como cualitativos que forjan la 'estética del vacío' que caracteriza a la serie creada por Matthew Weiner. Así, las imágenes finales de cada entrega componen una especie de pausado ritual en el que la forma televisiva retrata a un hombre solo, atrapado por un entorno opresor e incapaz de progresar dramáticamente.

Palabras clave: Estética televisiva; estilo; plano, Mad Men; estética del vacío.

Sumario: 1. Mad Men and Television Aesthetics. 2. Formal analysis of the shot: methodological aspects. 3. The aesthetic of the final shots of Mad Men: quantitative aspects. 4. Don Draper and the 'aesthetic of emptiness'. 5. Conclusions. References.

\footnotetext{
$1 \quad$ Universidad Pontificia de Salamanca (España)

E-mail: mahuertafl@upsa.es

2 Universidad Complutense de Madrid (España)

E-mail: ernesper@ucm.es
} 
Cómo citar: Huerta, M.A.; Pérez, E. (2019) Mad Men and television aesthetics: Final shots as a tool for textual configuration. Arte, Individuo y Sociedad 31(4), 825-838.

\section{Mad Men and Television Aesthetics}

Generally, academic examinations of AMC's Mad Men (2007-2015) confirm the idea that style is one of the least studied aspects of television as a medium of communication. The series is arguably one of the most critically acclaimed audiovisual productions of the twenty-first century, and since its launch in July 2007 , has been the subject of analysis using a variety of approaches and from a diverse mix of disciplines. In this way, political, historical, sociological and aesthetic perspectives - amongst others - have contributed to an understanding of the 92 episodes created or supervised by Matthew Weiner. Nevertheless, the formal codes from which they have been constructed have been relegated to a secondary position in comparison with the findings contributed by other disciplines. Amidst all of this analysis, it seems that the aesthetic dimension of the work has been largely ignored, an omission difficult to be explained, since there would be no text to examine from any point of view without a conscious articulation of its formal qualities.

The origin of this sidelining of the aesthetic aspect of television can be traced to the emergence of 'TV Studies' as a discipline in the seventies. As Glen Creeber states, with a few exceptions "the discipline tended to shy away from aesthetics. This was partly because its low cultural status often prevented it from being taken seriously as a form of artistic expression" $(2013$, p. 5). Amongst the exceptional cases that Creeber highlighted, some contributions made four decades ago stand out (Williams, 1974; Newcomb, 1974). The work of these authors has been used as the foundation for other seminal writing on the subject (Ellis, 1982; Thorburn, 1987; Caldwell, 1995). Thanks to the rigor of all these works, television aesthetics has evolved thus far in the twentieth century, driven to a large extent by the cultural phenomenon of serialized fiction and Quality TV. Thus, productions as disparate as The Sopranos (1999-2007), Six Feet Under (2001-2005), The Wire (2002-2008), Arrested Development (2003-), Lost (2004-2010), Mad Men and Homeland (2011-) have helped to curb the more intellectually reductionist outlooks and have opened the way to such intriguing concepts as that of "complex TV" (Mittell, 2015).

The outlook for academic exploration of this area might seem encouraging but its fruits continue to be insufficient. In spite of the thrust and value of the new results achieved by television aesthetics, it is enough to look into the existing bibliography about works like Mad Men to arrive at the conclusion that their scope continues to be comparatively residual. The story of Don Draper (Jon Hamm), a successful creative advertising agent in New York in the early sixties, has not only garnered critical praise $^{3}$ and relevant awards - amongst them the Emmy for Outstanding Drama

The critical recognition of the seven seasons and 92 episodes that make up Mad Men has been almost unanimous. The texts published in the New York Times (Stanley, 2007) and The Times (Billen, 2015) are valuable as examples of the evolution of the good media treatment received by a series regarded by a large percentage of specialists as a masterpiece. Nevertheless, it is worth pointing out some exceptions, like that of the critic from The Washington Post, who at the end of the first season criticized some qualities of the production like its dense rhythm and the pauses of the actors (Shales, 2007). 
Series for four years running from 2008 to 2011 - but also the curiosity of academics worldwide who yielded to a subject for study that had an undoubted capacity to beguile.

As a consequence of these factors, works abound analyzing the discourse created by Mad Men about the most varied topics: historical context (Hernandez and Holmberg, 2011; Polan, 2013), political reality (Lang, 2013; Beail \& Goren 2015), economy and modes of consumption (Gillan, 2011; Pierson, 2011; Edenborg, 2015), the concept of masculinity (Siska, 2011; Kaganovsky, 2013; Varon, 2013; Witzig, 2015), feminism (Murugan, 2011; Haralovich, 2011; Taylor, 2015), maternity (Davidson, 2011), homosexuality (Doty, 2013), fashion (Rosenheck, 2013), the idea of nostalgia (Sprengler, 2011; Stoddart, 2011) and the projection of the racial image (Perlman, 2011; Ono, 2013; Beail, 2015). Fascination with the series has also inspired monographs from classic disciplines like philosophy (Carveth \& South 2010) and psychology (Newman, 2012). Those examples, however, by no means exhaust the number and variety of academic explorations of the series.

Although the aesthetic qualities of Mad Men have been pushed into the background as far as academic attention is concerned, some notable exceptions can be highlighted. Some of the chapters included in the Edgerton's work stand out, particularly the one written by Butler (2011) that focuses on visual style. Rushing (2013), on the other hand, found stimulating relationships between Mad Men's staging and the movies of Antonioni. Furthermore, Vermeulen \& Rustad applied the concept of 'late' or 'delayed' cut to reflect on Mad Men as an example of quality TV (2013). Finally, Bort's doctoral thesis (2012) includes an interesting chapter about aesthetic elements in the series, such as the opening, the pre-ending and the ending, in a research project that partially shares some of our interests.

This paper is situated in similar disciplinary territory, adding to the body of work that recognizes the primacy of television aesthetics and the need to concentrate more academic attention on the area. The methodology is centered on the concept of a shot as a minimum unit of audiovisual meaning, based on which we can determine a series of values that enable us to draw relevant quantitative and qualitative conclusions about the textual configuration of the series.

\section{Formal analysis of the shot: methodological aspects}

Shot by shot analysis is a model aimed at dissecting the shots that make up a given audiovisual work. It has been used in the present work, which studies 22 individual aspects of each shot, so that they can be interconnected in search of possible meanings, senses and connotations. The procedure involves analyzing all the components of the image and its syntactical resources. Thus, both internal and external elements of the shot are studied, from scales and camera angles to transitions ${ }^{4}$.

\footnotetext{
In particular, the following aspects are analyzed, based on categories: 'Shot Number', 'Shot Length' and 'Placing' in the footage; 'Spatial Description' and 'Time Treatment'; 'Transition' (Cuts or Fades); 'Scale' and 'Angle', as well as 'Camera Movement'; 'Description of Actions', 'Dialogues' 'Sounds' and 'Music'; 'Costume, props and other items', 'Lighting and Photography' and 'Composition'. As an essential category regarding a bridge to inference, there is 'Sense', as well as those that enable interrelation e.g. 'Relationship with other shots' and 'Relationship with other movies or works'. The final category deals with 'Problems' the shot might present, 'Comments' are noted and 'Frames' are observed, whether for illustrative purposes or as evidence.
} 
There is no approach more painstaking than shot by shot analysis (Stam 2000, p. 222), heir to the textual analyses undertaken during the 1960s and 1970s by theoreticians like Thierry Kuntzel, Stephen Heath and Kari Hanet. Marie-Claire Ropars-Wuilleumier and Michel Marie also elaborated some notation schemes in which they recorded angles, sound types or camera movements, while the French magazine L'Avant-Scène Cinéma made decoupage into a habitual practice. These methods were subsequently employed in works like those of González (1995) and Pérez (2015). Finally, the works of Raymond Bellour must be mentioned, particularly L'analyse du film (1979) on the pertinence of applying information drawn from literary criticism to cinematographic studies.

The authors of this work understand that the television shot, in so far as form is concerned, feeds on very similar elements as those that give sense to the cinematographic shot. It is therefore possible to transfer this method to the subject being explored in this paper. This approach seems particularly appropriate given the facts that not only is Mad Men shot on 35mm Kodak color film, but Phil Abraham, director of 15 episodes, recognizes that the series "has a somewhat mannered, classic visual style that is influenced more by cinema than TV" (qtd. in Feld et al. 46).

This study is rooted in the logical-empirical method characteristic of psychological empirical analysis (León, 1991, p. 809). Analysis of this nature presupposes quantitative measurement, and focuses on the collection of data to assemble a database from which conclusions can be extrapolated. In the subsequent interpretative analysis the data is filtered using criteria developed from critical theory, and conclusions are considered from the perspective of subjective rationalism. This approach leaves the data open to different readings, because although the first part of the method (i.e. the material reading of signs) is the most 'objective', this does not confine the authors to the same results during subsequent stages of the research.

Formal elements like shot length, camera angle, direction of movement, etc., provide a solid and objective foundation for the analysis in this paper. As a result, it is necessary to set out precise, unquestionable bases, before moving on to descriptions of content or interpretations of sense. Opting for the shot as a minimum unit of audiovisual expression can be justified by drawing on debates that raged during the seventies concerning the specificity of cinematographic language; the frame is materially imperceptible as well as lacking in movement, while the scene or the sequence as units are too broad, and would reduce the precision of the analysis.

The choice of the final shots as the subject of this paper stems from the hypothesis that, due to the structure of the episodes of Mad Men and the conclusive character of the shots, they have a special relevance in the construction of the series as a text. This position is based on a series of formal resources that define the audiovisual personality of the work, and its particular aesthetic proposal. Therefore, this is about checking if the last shots generate a kind of ending in the episodes and if all together make up continuities of a formal nature, to the extent of generating a sort of distinctive feature of the work which is coherent with its most profound sense. 


\section{The aesthetic of the final shots of Mad Men: quantitative aspects}

An average of the results obtained by studying episodes of Mad Men indicates that the typical final shot lasts for 14.6 seconds. It is usually situated in doors, at night, and begins and ends with a cut as a means of transition. The scene is usually framed in a medium long shot with the camera motionless, within which Don Draper is the sole, passive protagonist. There is no dialogue, and no sound, except for an extradiegetic song contemporary to the dramatic action. These are the basic, objective results of an initial quantitative analysis, and need to be placed in context.

Since the serialized television plot is largely determined by temporariness and fragmentation, duration is one of the measurement criteria that define the shot. In fact, some influential works (O'Brien, 2005; Salt, 2006; Bordwell, 2006) reveal the use of the Average Shot Length (ASL) of an audiovisual text to draw aesthetic conclusions about cinematographic works, something that can be extrapolated to the television medium.

The ASL of the final shots of the episodes of Mad Men is 14.6 seconds. If this fact is observed by season, the greatest variation is between 9.5 seconds in the fifth and 18.4 in the third ${ }^{5}$. The figure acquires a heightened relevance when compared with the 5.2 seconds that Butler assigns to the average of all the shots of the episodes that make up the entire first season (Butler, 2011, p. 68), since the final shots of that first set of 13 episodes have an ASL of 17.1 seconds, a significantly longer duration.

Regarding the use of stage sets, $79 \%$ of the final shots of the episode use an interior setting as opposed to $21 \%$ of exterior settings. There are some notable variations, as all 13 episodes of the fourth season end with interiors as opposed to the greater balance ( 6 exteriors and 8 interiors) in the seventh and final season ${ }^{6}$. In addition to the preference for locating the closing shots of the installments in interiors there is an inclination towards domestic settings ( 35 out of 73 shots in interior sets, $48 \%$ ) and professional settings ( 26 out of 73 shots, $35.6 \%$ ). To those must be added means of transport (cars, trains and planes add up to 5 final shots, $6.8 \%$ ), places of leisure (4 shots, $5.5 \%$ ) and various others ( 3 in total, $4.1 \%$ ).

The moment when the action of each episode ends does not present great differences between the two main choices in terms of narrative and production, i.e. day or night. Overall, $52 \%$ of the final shots are set at night-time as opposed to $48 \%$ that end during the day. Among seasons a tendency towards balance is noted, except for the third (11 of 13 possible final shots being night) and fourth seasons ( 9 day shots out of 13). Whatever the case, there is a greater tendency to choose night-time shots in the earlier seasons compared with the later ones, where most of the final shots take place in daylight ${ }^{7}$.

Specifically, the ASL per season of the final shots is the following: Season 1: 17.1 seconds, Season 2: 15.6 seconds, Season 3: 18.4 seconds, Season 4: 12.1 seconds, Season 5: 9.5 seconds, Season 6: 11.6 seconds, and Season 7: 18.1 seconds.

6 The complete figures per season are as follows: Season 1: 3 exterior/10 interior, Season 2: 4 exterior/9 interior, Season 3: 3 exterior/10 interior, Season 4: 0 exterior/13 interior, Season 5: 1 exterior/12 interior, Season 6: 2 exterior/11 interior, and Season 7: 6 exterior/8 interior.

7 The complete results per season are as follows: Season 1: 4 day/9 night, Season 2: 7 day/6 night, Season 3: 2 day/11 night, Season 4: 9 day/4 night, Season 5: 6 day/7 night, Season 6: 8 day/5 night, and Season 7: 8 day/6 night. 
On the other hand, editing involves the application of transition techniques that are noted at both the beginning and end of each shot. In this sense, on the majority of occasions Mad Men settles for cut/cut combinations, rising to a total of $67.3 \%$, a considerable figure given the high number of possible combinations. The cut/fade to black alternative reaches $27.3 \%$, the other options being practically residual: $2.2 \%$ fade to black/fade to black, $2.2 \%$ dissolve/fade to black, $1 \%$ dissolve/cut. Moreover, there are no important differences among seasons ${ }^{8}$.

Camera behavior and movement constitutes another style trait that must be taken into consideration in determining the aesthetic personality of an audiovisual work. In $52.2 \%$ of the final shots of the series the camera remains motionless, while in $47.8 \%$ of cases it makes some kind of movement. That apparent balance is not an absolute constant throughout the seasons, since there are significant differences between, for example, 11 moving out of the 13 final shots counted in the first season as opposed to 10 stills out of the 13 final shots in the fifth ${ }^{9}$.

The variable of shot size or image scale is rather more difficult to measure. This difficulty is less in the $68.5 \%$ of cases that refer to a single scale, since there are no significant movements of the characters or the camera to alter the image size. Within this majority block the more open shots, i.e. those greater than the medium shot, stand out. The mid shots, American shots, medium long shots, long shots and big long shots amount to 35 out of the 92 shots, or $38 \%$ of the total. That favorite amongst directors, the medium long shot, which ends an episode on 12 occasions out of 92 .

Handling the data becomes more complex when considering the myriad of variables that arise in $31.5 \%$ of the cases that include relevant changes of scale within the same shot, whether growing progressively larger (19 out of 92) or smaller (10 out of 92). In this group, the mid shot stands out, and often ends up becoming a medium long shot ( 7 out of $92,7.6 \%$ of the total), another 7 shots end up at that scale, which the directors undoubtedly insisted upon for the end of each episode.

Scales are most often built based on the dramatic action the characters carry out in the visual field. Regarding the behavior of these in the final shots, the omnipresence of Don Draper must be pointed out, his figure being notable in 65 of the 92 shots, more than $70 \%$ of the total ${ }^{10}$. In 33 of them, the character appears alone in the shot, whether because the camera singles him out within the framing of a setting in which there are more people (which occurs on 4 occasions) or because there is no-one else (occurs 29 times). Moreover, within this final set Don behaves passively in 15 of the 29 shots, having an active attitude in 12. There are 2 cases in which he shows significant activity at the beginning of the shot but ends up adopting a notable passivity.

\footnotetext{
Shot combinations are as follows: Season 1: cut-cut: 8/13; cut-fade to black: $3 / 13$; fade to black-fade to black: 2/13. Season 2: cut-cut: $6 / 13$; cut-fade to black: $6 / 13$; dissolve-cut: $1 / 13$. Season 3 : cut-cut: $9 / 13$; cut-fade to black: 3/13; dissolve-fade to black: $1 / 13$. Season 4: cut-cut: $9 / 13$; cut-fade to black: $3 / 13$; dissolve-fade to black: 1/13. Season 5: cut-cut: 10/13; cut-fade to black: 3/13. Season 6: cut-cut: 10/13; cut-fade to black: 3/13. Season 7: cut-cut: 10/14; cut-fade to black: $4 / 14$.

9 For this variable the complete data is as follows: Season 1: 2 still/11 moving. Season 2: 7 still/6 moving. Season 3: 7 still/6 moving. Season 4: 8 still/5 moving. Season 5: 10 still/3 moving. Season 6: 9 still/4 moving. Season 7: 5 still/9 moving.

10 It is particularly significant that the protagonist appears in $100 \%$ of the final shots of the seventh season, which ended the series. In the other cases a greater variety is noticed: Season 1: 7/13, Season 2: 9/13, Season 3: 11/13, Season 4: 11/13, Season 5: 4/13, and Season 6: 9/13.
} 
The aesthetic of the final shots of each episode of Mad Men is also defined by means of sound. In this sense, $80.4 \%$ of the final shots do not include any dialogue, while in $19.6 \%$ the characters speak the odd word out loud ${ }^{11}$. Other parameters reveal, however, a more elaborate charge, especially in $65.2 \%$ of occasions when some extradiegetic song contemporaneous to the time of the dramatic action sounds in the background. As for the frequency of use, the following option is also situated outside the world of the TV series, specifically on $21.7 \%$ of the occasions when the original soundtrack of the series sounds. The occasions when no kind of music is used amount to $10.9 \%$, the remaining $2.2 \%$ being music and songs set in the action and which therefore have a diegetic nature.

\section{Don Draper and the 'aesthetic of emptiness'}

The devices described bring to light a series of stylistic conventions that precisely define the final shots of each episode of Mad Men. The fragments analyzed form an episodic and consistent ending in the continuity of a work that handles, as two of its main themes, the configuration of personal identity and the individual's fall into the abyss in a very specific historical context, as reflected in the opening credit sequence of the series.

Don Draper, the hegemonic protagonist, is in a permanent conflict between his own identity and the space that surrounds him, without dramatic progression seeming to be an option. Moreover, it could be stated that the aesthetic of the final shots reproduces in audiovisual terms the internal conflict of a character who feels imprisoned inside himself. For this reason, the final shots of the series do not usually utilize the functionality that many series resort to: the cliffhanger, a typically unexpected happening that closes the episode with the intention of causing a strong sensation of intrigue in the viewer. Habitually Mad Men moves in a territory that mixes the reflective with the emotional, two outlooks united in what could be classed as an 'aesthetic of emptiness'.

The editing contributes to the design, and generates a sensation of time standing still or being suspended. The aforementioned ASL of 14.6 seconds of the sample is set in the context of the operation we are characterizing, and is consistent with the production strategies of AMC. Exactly as Smith explains, the company responsible for broadcasting Mad Men usually breaks with conventions of audiovisual rhythm where the facts of the plot tend to be presented in series belonging to the ad-supported model. Thus, in the face of the much shorter ASL of productions like CSI: Crime Scene Investigation (CBS, 2000-2015) or 24 (Fox, 2001-2010), AMC tends to use editing to take considerably longer, given its bid for "Slow-Burn Narratives" (Smith 2013, 150).

This style marker is also evident in the ASL of the final shots of some of the channel's most emblematic series. If in the case of Mad Men the data was 14.6 seconds, we found similar results, e.g.14.4 seconds in the case of Breaking Bad

11 In this regard too, significant deviations between seasons are not noticed. Season 1: 5 dialogue/8 without dialogue, Season 2: 2 dialogue/11 without dialogue, Season 3: 3 dialogue/10 without dialogue, Season 4: 2 dialogue/11 without dialogue, Season 5: 2 dialogue/11 without dialogue, Season 6: 2 dialogue/11 without dialogue, and Season 7: 2 dialogue/12 without dialogue. 
(2008-2013), 15.6 in that of Rubicon (2010), 11.3 in that of The Walking Dead (2010-), and 10 in that of The Killing (2011-2014). The endings of each installment reveal a similar tendency towards the expansion of time so that the viewer can draw conclusions, while the narrative effect it tries to cause presents notable differences depending on each work.

As far as Mad Men is concerned, the unhurried rhythm also corresponds to the regularity with which Don Draper appears in an introspective attitude, as if he were in the final stages of a profound inner conflict without expectations of it being resolved. In addition, the temporal necessity is imposed not only by dramatic logic, but rather it is integrated into what Vermeulen and Rustad call the "late/delayed cut". Thus, the series "seems to appreciate both the plot and the place, the action and the descriptive, the character and the subject, equally" (Vermeulen \& Rustad, 2013, p. 11). As a result of that spirit, the camera often reaches the scene before the action takes place and remains there for some time after it has finished.

The interesting contribution by Vermeulen \& Rustad helps to channel the rest of the aesthetic findings gained from our observation of the final shots. If the numerical data reveal an image model characterized by interior settings, static mid shots and the framing of the protagonist in a silent and passive attitude, it is because broadly speaking, the show aims to reiterate that what is important is not so much the character conceived as a vehicle for the action as the hostile relationship he maintains with the dramatic space. Moreover, the repetition of visual motifs reinforces the idea that the passing of time scarcely involves advances or profound changes for Don.

Many of these visual motifs have to do with the impossibility of the home as a space of affirmation and happiness. During the first three seasons, the Draper family home has the idyllic appearance of the typical middle/upper class residential complex away from Manhattan ${ }^{12}$. Nevertheless, the welcoming look the stage set confers on this space is contradicted by the way in which the protagonist lives in it. There is a good example in Season 1: Episode 13 thanks to the framing of Don downcast and pensive, the visual rhyme of his dark clothing with the first floor of the house, the reframings set up by the vertical forms that stand out in the composition and the reverse tracking that establishes a link between the character and his home. Don is solitary at that moment since his wife Betty (January Jones), has gone with the children to spend a few days away.

The device is repeated during the second season, specifically in the final shot (2:06) where Draper stops shaving to sit on the W.C. in the bathroom with an expression of being deep in thought. At that moment the camera moves backwards to create a double frame thanks to the doorframe, a second focus of attention emerging thanks to a mirror reflecting the figure of Don. The aesthetic devices in these cases serve to enclose the individual by means of the proliferation of rigid geometric shapes while adding to the sense of his conflicted relationship with the rest of the home. These elements are often emphasized in other episode endings $(1: 02 ; 2: 08)$.

Even when all these strategies are not used in combination with each other, the stage set during the first three seasons boosts the idea of the absence of harmony between the individual and his home, either because of a lack of communication with his wife $(1: 12 ; 2: 13)$, or because the protagonist is the only member of the

To be specific, the Draper family home is located in Ossining, a tiny town in the north of New York state, 34 miles from Madison Avenue, Manhattan, where the advertising agency Draper works for is located. 
family who turns his back to the camera (2:05), or because the actor is exhibiting an introspective and sad expression $(3: 04 ; 3: 08)$. It is also noticeable that only in the cases where Draper is with his children do his attitudes and the compositions of the images soften $(1: 03 ; 3: 01 ; 3: 06)$.

The tension between the main character and the pleasant appearance of the house relaxes curiously in the final shots of the fourth season, just when Don installs himself in a bachelor apartment in Manhattan. The close of the previous season (3:13) served as a prelude, with the long shot of a facade decorated with Christmas motifs that Draper looks at while a crane shot moves smoothly upwards. From then on, the episode endings that take place inside the house trace the course of the protagonist's love life, as he kisses the head of his partner Faye Miller (Cara Buono) (4:11) to just two episodes later (4:13) as he lies in bed with Megan Calvet (Jessica Paré), his future wife.

His return to marriage in the fifth season sets up a return to Draper's conflict with the home. From then on, the series employs the expressive potential of the final shots in an even more sophisticated way with visual devices that sum up a good part of the protagonist's private life. Specifically, two very intriguing visual rhymes can be appreciated between endings: in the first of them, Don passes from resolutely crossing a room framed in a long shot, warmly lit, dynamic thanks to the diagonals created by the furniture and tinged with a comfortable atmosphere (5:08), to a frame of similar size as the previous room dominated by him stopping in his tracks on discovering that the furniture has disappeared after his separation from Megan, creating a sense of emptiness and a static feeling that symbolically describes the end of the emotional relationship, and once again, the impossibility of the home (7:09). In the second rhyme, the stage set establishes a different connection between ending shots $(6: 03 ; 7: 10)$ that are set in the passage that comes before the entrance to the house, composed frontally and framed in a mid-shot scale. In 6:03 the character refuses to enter and sits on the ground as if he lacks the will to go inside. In 7:10, almost identically, Don turns around to look at the passageway when a gentle reverse tracking begins that serves not only to end the episode but also adds the final confirmation of the impossibility of a stable life as a couple, symbolized by the motif of an inaccessible home.

Compared to those previous episodes, Don and Megan's matrimonial home presents the singularity of the outdoor scene on the terrace where, interestingly, both she $(5: 01)$ and he $(6: 05)$ take refuge separately in two endings with very similar aesthetic values. This makes clear the difficulty of their relationship, and it is no coincidence that the big city is used as the backdrop. The terrace is finally revealed as a useless means of escape from the prison of marital life, an idea movingly expressed when, time having passed (7:01), Don sits by a side wall gazing into space and breathing agitatedly. That shot depicts him in domestic clothing - dark bathrobe, white T-shirt - a position facing the camera, plenty of dense night-time shadows and a reverse tracking that progressively makes his figure smaller, formally expressing the image of isolation.

On the other hand, the aesthetic combinations of the final shots in relation to the failed utopia of the home show a notable consistency regardless of the passing seasons. It is of no account that one episode is shown for the first time at the end of July 2008 (1:12) and another in May 2013 (6:07), and even the diegetic time that passed between Richard Nixon's congratulatory speech to John F. Kennedy 
in 1960 and the assassination of Bobby Kennedy in 1968 lacks importance, these events being referred to by a television that is placed in the action at the close of the respective episodes. The aesthetic device on both occasions underlines the theme of the couple's lack of communication in the face of relevant happenings retransmitted by mass media and so influential in public opinion. Specifically, Don looks at the television broadcast in the first case with an offhand air while Betty is sleeping, whereas in the second Megan pays attention sorrowfully to a television with her back to Don, who opts for staring at the floor, fixing his attention on his own personal crisis.

The stability in the use of the domestic space as a place that fosters the emergence of inner conflicts has its counterpoint in the professional sphere, where the aesthetic of the final shots generates a wider range of significance around the protagonist. Especially during the first few seasons, an accentuated dynamism is imparted in the closing shots that take place at the Sterling Cooper agency. One of them (1:08) particularly stands out as being exceptional within the sample analyzed: in the interior of the office, the camera is placed in an oblique position and captures the back door of Don's office. Suddenly he enters from the left of the frame and, with his back to the camera, moves decisively towards his workplace. The camera accompanies him in a forward tracking motion that stops just as he closes the door. At this moment, what remains on the screen is the detail of the official plaque with his name on the door. The choreography is very complex due to both the internal rhythm and the variety of compositions and scales that are used as the shot develops, and reinforces the vigor of the identity built by the protagonist, much firmer in the professional than the family sphere.

The proactive Don of the final shots in the office is a general tonic during the first three seasons, especially when the internal rhythm, depth of field and camera movement combine in the building of a very complex and dynamic aesthetic (3:02). Nevertheless, from the fourth season onward, this is tempered with a tendency towards the static and more close-up scales that intensify Draper's generally bewildered reactions $(4: 03 ; 4: 10 ; 4: 12 ; 6: 01 ; 7: 03 ; 7: 04)$. Curiously, it is at the agency that bears his surname as a partner - Sterling Cooper Draper Pryce, founded at the end of the third installment - that rather intriguing closing shots become more habitual e.g. that of Don in the boardroom (5:06), trapped by a complex network of rectangles created by doors and windows, barely supporting himself against the table and leaning in a faint towards the left of the frame. The camera position unbalances the subject and places him in a hostile and empty context.

This intriguing composition will visually rhyme, of course, with a different one (6:09) taken from the same viewpoint but with Peggy situated at the other side of the picture window and outside a boardroom into which she gazes transfixed. In this way, the stage set describes how the place that for Don is a source of conflict during the final section of the series continues to be a prohibited space for her despite her effort to conquer it from the beginning of the story. The glass roof that interposes before the young woman thus acquires the physiognomy of the glass wall that signifies the spot from where the agency's future is decided.

The interior scenes, often oppressive, have their counterpoint in the minority of cases of those endings that take place outdoors. These generally maintain a narrative relationship with Don's past and his true identity $(2: 01 ; 2: 12 ; 6: 13)$ and seek more 
friendly compositions dominated by the sea or sky, in this way distancing from the geometric rigidity that characterizes the closed spaces.

In spite of everything, it cannot be ignored that the three final episodes $(7: 12 ; 7: 13$; 7:14) of Mad Men locate their endings in natural exterior settings of great luminosity, very warm and inviting, presided over by clear skies and marked by an intense depth of field. The search Don seems to be undertaking of his deepest self culminates in the final installments in an aesthetic arsenal that enriches the general style of the series and acts as a contrast in the construction of a supposed individual liberation. Nevertheless, all is revealed as Draper's umpteenth ploy when it is disclosed that what he really discovers is the idea for a Coca Cola advertising campaign, ironically expressed with the slogan "It's the real thing".

\section{Conclusions}

As we have seen, the quantitative and qualitative results of the analysis of the values that make up the final shots of each episode of Mad Men make an important contribution to the in-depth knowledge of the series. The method used has proven both suitable and valuable, since as well as validating the formal personality of the sample through objective data it enables the formulation of stimulating inferences that assist in understanding the aesthetic of a series analyzed in great detail from other academic perspectives.

Nevertheless, it is worth recognizing some limitations of the results obtained. The sample based on the final shots of episode has an important symbolic and functional value in the series narrative, the more so when the broadcasts are originally conceived for weekly viewing. There are many possible selections of units for study that will certainly broaden the range of aesthetic strategies employed by such a complex work and minutely conceived in every single one of its images.

For now, the final shots of the episodes of Mad Men are registered as possessing a relevant personality in the creation of an aesthetic of the individual incapable of handling problems with self-identity and who is in constant conflict with parts of his environment. Emptiness, the impossibility of the home, and loneliness ultimately make up the most outstanding arsenal of concepts to which the ending of each installment of the series lends audiovisual form. The long duration of most of the analyzed units, the nocturnality, the immobility of the representation, the search for compositions that highlight the loneliness of the protagonist and the tendency not to use dialogues reinforce the inclination towards a profound synthesis and reiterative willingness that the last images of the episodes have. Thus, the series achieves the creation of a very distinguishable convention with respect to other series and requires the aesthetic approach so as to understand its most profound sense.

\section{References}

Beail, L. (2015). Invisible Men: The Politics and Presence of Racial and Ethnic "Others" in Mad Men. In L. Beail \& L. J. Goren (Eds.), Mad Men and Politics. Nostalgia and the Remaking of Modern America (pp. 231-256). New York: Bloomsbury. 
Beail, L. \& Goren, L. J. (2015). Mad Men and Politics: Nostalgia and the Remaking of America. In L. Beail \& L. J. Goren (Eds.), Mad Men and Politics. Nostalgia and the Remaking of Modern America (pp. 3-34). New York: Bloomsbury.

Bellour, R. (1979). L'analyse du film. Paris: Albatros.

Billen, A. (2015, May 22). Mad Men finale: a fitting end for this American masterpiece. The Times. Retrieved from https://www.thetimes.co.uk/article/mad-men-finale-a-fitting-endfor-this-american-masterpiece-vfg83g669h8

Bordwell, D. (2006). The Way Hollywood Tells It. Story and Style in Modern Movies. Berkeley: University of California Press.

Bort, I. (2012). Nuevos paradigmas en los telones del relato audiovisual contemporáneo: particulas narrativas de apertura y cierre en las series de televisión dramáticas norteamericanas (Tesis doctoral). Universitat Jaume I, Castellón, España.

Butler, J. G. (2011). Smoke Gets in Your Eyes: Historicizing Visual Style in Mad Men. In G. R. Edgerton (Ed.), Mad Men: Dream Come True (pp. 55-71). London: I. B. Tauris.

Caldwell, John T. (1995). Televisuality: Style, Crisis and Authority in American Television. New Brunswick: Rutgers University Press.

Carveth, R. \& South, J. B. (Eds.). (2010). Mad Men and Philosophy: Nothing Is at It Seems. New Jersey: John Wiley \& Sons.

Creeber, G. (2013). Small Screen Aesthetics. From TV to the Internet. London: Palgrave Macmillan.

Davidson, D. (2011). “A Mother Like You”: Pregnancy, the Maternal, and Nostalgia. In S. F. Stoddart (Ed.), Analyzing Mad Men. Critical Essays on the Television Series (pp. 136154). Jefferson: McFarland.

Doty, A. (2013). The Homosexual and the Single Girl. In L. M. E. Goodlad, L. Kaganovsky \& R. A. Rushing, Mad Men, Mad World. Sex, Politics, Style \& the 1960s (pp. 279-299). Durham: Duke University Press.

Edenborg, K. (2015). Going Groovy or Nostalgic: Mad Men and Advertising, Business, and Social Movements. In L. Beail \& L. J. Goren (Eds.), Mad Men and Politics. Nostalgia and the Remaking of Modern America (pp. 147-172). New York: Bloomsbury.

Edgerton, G. R. (Ed.) (2011). Mad Men: Dream Come True. London: I. B. Tauris.

Ellis, J. (1982). Visible Fictions: Cinema, Television, Video. London: Routledge.

Feld, R., Oppenheimer, J. \& Stasukevich, I. (2008). Tantalizing Television. American Cinematographer: The International Journal of Film \& Digital Production Techniques 89.3, 46-57.

Gillan, J. (2011). Kodak, Jack, and Coke: Advertising and Mad-vertising. In S. F. Stoddart (Ed.), Analyzing Mad Men. Critical Essays on the Television Series (pp. 95-114). Jefferson: McFarland.

González, J. (1995). El análisis cinematográfico. Modelos teóricos, metodologías, ejercicios de análisis. Madrid: Editorial Complutense.

Haralovich, M. B. (2011). Women on the Verge of the Second Wave. In G. R. Edgerton (Ed.), Mad Men: Dream Come True (pp. 159-176). London: I. B. Tauris.

Hernandez, M. \& Holmberg, D. T. (2011). We'll start over like Adam and Eve: The Subversion of Classic American Mythology. In S. F. Stoddart (Ed.), Analyzing Mad Men. Critical Essays on the Television Series (pp. 15-44). Jefferson: McFarland.

Kaganovsky, L. (2013). "Maidenform". Masculinity as Masquerade. In L. M. E. Goodlad, L. Kaganovsky \& R. A. Rushing (Eds.), Mad Men, Mad World. Sex, Politics, Style \& the 1960s (pp. 238-256). Durham: Duke University Press. 
Lang, C. (2013). Representing the Mad Margins of the Early 1960s. Northern Civil Rights and the Blues Idiom. In L. M. E. Goodlad, L. Kaganovsky \& R. A. Rushing (Eds.), Mad Men, Mad World. Sex, Politics, Style \& the 1960s (pp. 73-91). Durham: Duke University Press.

León, J.L. (1991). Investigación y métodos. In A. Benito (Ed.), Diccionario de Ciencias y Técnicas de la comunicación (pp. 806-822). Madrid: Ediciones Paulinas. Mittell, J. (2015). Complex TV. The Poetics of Contemporary Television Storytelling. New York: New York University Press.

Murugan, M. L. (2011). Maidenform: Temporalities of Fashion, Feminity, and Feminism. In S. F. Stoddart (Ed.), Analyzing Mad Men. Critical Essays on the Television Series (pp. 166-185). Jefferson: McFarland.

Newcomb, H. (1974). TV: The Most Popular Art. New York: Anchor Books.

Newman, S. (2012). Mad Men on the Couch: Analyzing the Minds of the Men and Women of the Hit Tv Show. New York: Thomas Dunne Books.

O'Brien, Ch. (2005). Cinema's Conversion to Sound. Technology and Film Style in France and the U.S. Bloomington: Indiana University Press.

Ono, K. (2013). Mad Men's Postracial Figuration of a Racial Past. In L. M. E. Goodlad, L. Kaganovsky \& R. A. Rushing (Eds.), Mad Men, Mad World. Sex, Politics, Style \& the 1960s (pp. 300-319). Durham: Duke University Press.

Pérez, E. (2015). El estudio 'plano a plano' como nuevo método de análisis fílmico. Observatorio $\left(O B S^{*}\right)(9.2), 93-118$.

Perlman, A. (2011). The Strange Career of Mad Men: Race, Paratexts and Civil Rights Memory. In G. R. Edgerton (Ed.), Mad Men: Dream Come True (pp. 209-225). London: I. B. Tauris.

Pierson, D. P. (2011). Unleashing a Flow of Desire: Sterling Cooper, Desiring-Production, and the Tenets of Late Capitalism. In S. F. Stoddart (Ed.), Analyzing Mad Men. Critical Essays on the Television Series (pp. 79-94). Jefferson: McFarland.

Polan, D. (2013). Maddening Times. Mad Men in Its History. In L. M. E. Goodlad, L. Kaganovsky \& R. A. Rushing (Eds.), Mad Men, Mad World. Sex, Politics, Style \& the 1960s (pp. 35-52). Durham: Duke University Press.

Rosenheck, M. (2013). Swing Skirts and Swinging Singles. Mad Men, Fashion, and Cultural Memory. In L. M. E. Goodlad, L. Kaganovsky \& R. A. Rushing (Eds.), Mad Men, Mad World. Sex, Politics, Style \& the 1960s (pp. 161-180). Durham: Duke University Press.

Rushing, R. A. (2013). "It Will Shock You How Much This Never Happened". Antonioni and Mad Men. In L. M. E. Goodlad, L. Kaganovsky \& R. A. Rushing (Eds.), Mad Men, Mad World. Sex, Politics, Style \& the 1960s (pp. 192-210). Durham: Duke University Press.

Salt, B. (2006). Moving Into Pictures. More on Film History, Style, and Analysis. London: Starword.

Shales, T. (2007, Jul 19). AMC's 'Mad Men': A Bunch of Cutthroats Without and Edge. The Washington Post. Retrieved from http://www.washingtonpost.com/wp-dyn/content/ article/2007/07/18/AR2007071802733.html

Siska, W. (2011). Men Behaving as Boys: The Culture of Mad Men. In G. R. Edgerton (Ed.), Mad Men: Dream Come True (pp. 195-208). London: I. B. Tauris.

Smith, A. N. (2013). Putting the Premium into Basic: Slow-Burn Narratives and the LossLeader Function of AMC's Original Drama Series. Television \& New Media 14.2, 150-66.

Sprengler, Ch. (2011). Complicating Camelot: Surface Realism and Deliberate Archaism. In S. F. Stoddart (Ed.), Analyzing Mad Men. Critical Essays on the Television Series (pp. 234-252). Jefferson: McFarland. 
Stam, R. (2000). Film Theory. Malden: Blackwell.

Stanley, A. (2007, Jul 19). Smoking, Drinking, Cheating and Selling. The New York Times. Retrieved from http://www.nytimes.com/2007/07/19/arts/television/19stan.html

Stoddart, S. F. (2011). Camelot Regained. In S. F. Stoddart (Ed.), Analyzing Mad Men. Critical Essays on the Television Series (pp. 207-233). Jefferson: McFarland.

Taylor, N. F. 2015. "You Can't Be a Man. So Don't Even Try": Femininity and Feminism in Mad Men". In L. Beail \& L. J. Goren (Eds.), Mad Men and Politics. Nostalgia and the Remaking of Modern America (pp. 207-230). New York: Bloomsbury.

Thorburn, D. (1987). Television as an Aesthetic Medium. Critical Studies in Mass Communication (4), 161-173.

Varon, J. (2013). History Gets in Your Eyes. Mad Men, Misrecognition. In L. M. E. Goodlad, L. Kaganovsky \& R. A. Rushing (Eds.), Mad Men, Mad World. Sex, Politics, Style \& the 1960s (pp. 257-278). Durham: Duke University Press.

Vermeulen, T. \& Gry C. R. (2013). Watching television with Jacques Ranciére: US 'Quality TV', Mad Men and the 'late cut'. Screen (54.3), 341-354.

Williams, R. (1974). Television: Technology and Cultural Form. London: Routledge.

Witzig, D. (2015). Masculinity and its Discontents: Myth, Memory, and the Future on Mad Men. In L. Beail \& L. J. Goren (Eds.), Mad Men and Politics. Nostalgia and the Remaking of Modern America (pp. 175-206). New York: Bloomsbury. 